\title{
Compensation, Job Stress, and Job Satisfaction on Nurse Turnover Intention at Ananda Bekasi Hospital
}

\author{
Novi Amanda ${ }^{*}$ Rina Anindita ${ }^{*}$, M. Reza Hilmy* \\ *Master Program of Hospital Administration, Esa Unggul University Jakarta \\ Email: amanda.novi81@gmail.com
}

\section{ABSTRACT}

One of the high turnover rates in the hospital occurs in nurses which is a disadvantageous to the hospital in terms of cost, resources, and effectiveness of nursing. This research aims at empirical evidence on the effect of compensation, job stress and job satisfaction on turnover intention at Ananda Bekasi Hospital. Research method was causality design based on the time dimension of one short study. The sample used was saturated sampling, that was, the entire population was sampled for 100 inpatient nurses. The data analysis method used Three box Method and Multiple Linear Regression Analysis. Turnover Intention, Job stress and Compensation Variable lie within the medium categories using three-box method as well as the Job Satisfaction variable. The results found no negative and significant effect between compensation for turnover intention. There was a positive and significant effect between job stress on turnover intention. There was a negative and significant effect between job satisfaction on turnover intention, and there was an influence between compensation, job stress and job satisfaction on turnover intention. Research findings was that most influences turnover intention variable is job stress. Managerial implications for Ananda Bekasi Hospital to calculate salaries based on the remuneration system, to establish appropriate assignment system, conduct workload analysis and to develop nurse career path.
Keywords: Turnover Intention, Compensation, Job stress, Job Satisfaction

\section{INTRODUCTION}

Nurses play an important role in executing medical actions, overseeing, or controlling the condition and development of patients who are in care. Turnover intention is a desire to leave the company. Various factors that influence the desire of employees to leave the company include job stress, job satisfaction and employee commitment to the company. The results of previous studies ${ }^{1}$ indicate that job satisfaction, and job stress have an influence on employee turnover of $45.1 \%$ and $54.9 \%$ influenced by other factors. One of the high turnover rates in the health care industry which in this case is the hospital occurs to nurses because nurses are one of the most staff in the hospital. $\mathrm{Hart}^{3}$ stated that intention to leave said that nurses turnover rates in hospitals were the highest compared to other similar jobs which applied technical skills (18-26\% annually). ${ }^{4}$ To be able to have the expertise, a nurse must have adequate work experience so that his or her clinical privileges become various. Therefore, it is important for a hospital to be able to keep the nurses from moving to work elsewhere.

In accordance with the vision of Ananda Bekasi Hospital, which is to be a hospital that provides high-quality health services, prioritizing patient safety, and be the choice of the community, the services provided to patients must be excellent. To provide quality services and based on patient safety, the hospital must be supported by professional 
health workers in their fields. The problem that occurs is the high turnover intention rate of nurses from year to year exceeds the optimum standard of $10 \%$ per year. Some indications that occur are the effect of job stress, compensation, and job satisfaction on nurses due to high work demands trigger nurses' desire to leave. Based on those indications, this study was designed to discover the effect of compensation, job stress, and job satisfaction on Turnover Intention of inpatient nurses at Ananda Bekasi Hospital.

\section{METHOD}

This research design uses a causal design with a time dimension of one short study. Data collection was carried out by distributing questionnaires by the researcher herself. The measurement method of this study uses the Likert scale method. Samples were inpatient nurses in Ananda Bekasi Hospital. The number of samples taken in this study was 100 people. Data analysis uses multiple linear regression analysis and total index value using the criteria of 3 boxes (Three-box Method). Tests used in this research are $F$ Test using ANOVA, t-test, and $\mathrm{R}$-squared $\left(\mathrm{R}^{2}\right)$ to measure the proportion of the variance for a dependent variable (turnover intention) that is explained by independent variables (compensation, job stress and job satisfaction) in a regression model $^{4}$.

Turnover intention variable is defined as the result of individual evaluation regarding the continuation of employees' relationship with the company where they work but has not been realized in real action or the desire or intention of the employees to quit their job ${ }^{4}$. In this study, the compensation variable is defined as any form of payment or reward given to hospital employees resulting from all the hard work of the employees. The stress of work is what happens when the ability of an individual is incapable of the workload he or she is carrying ${ }^{5}$. The occupational stress variable in this study translated as the perception of hospital employees to the conditions that occurred because of interactions between themselves and their work that were characterized by changes that deviated from their normal functions.

The research hypothesis is formulated as follows:

H1: Compensation affects turnover intention.

$\mathrm{H} 2$ : Job stress affects turnover intention.

H3: Job satisfaction affects turnover intention. H4: Compensation, job stress, and job satisfaction affect turnover intention.

The theoretical framework of this research is shown below. 


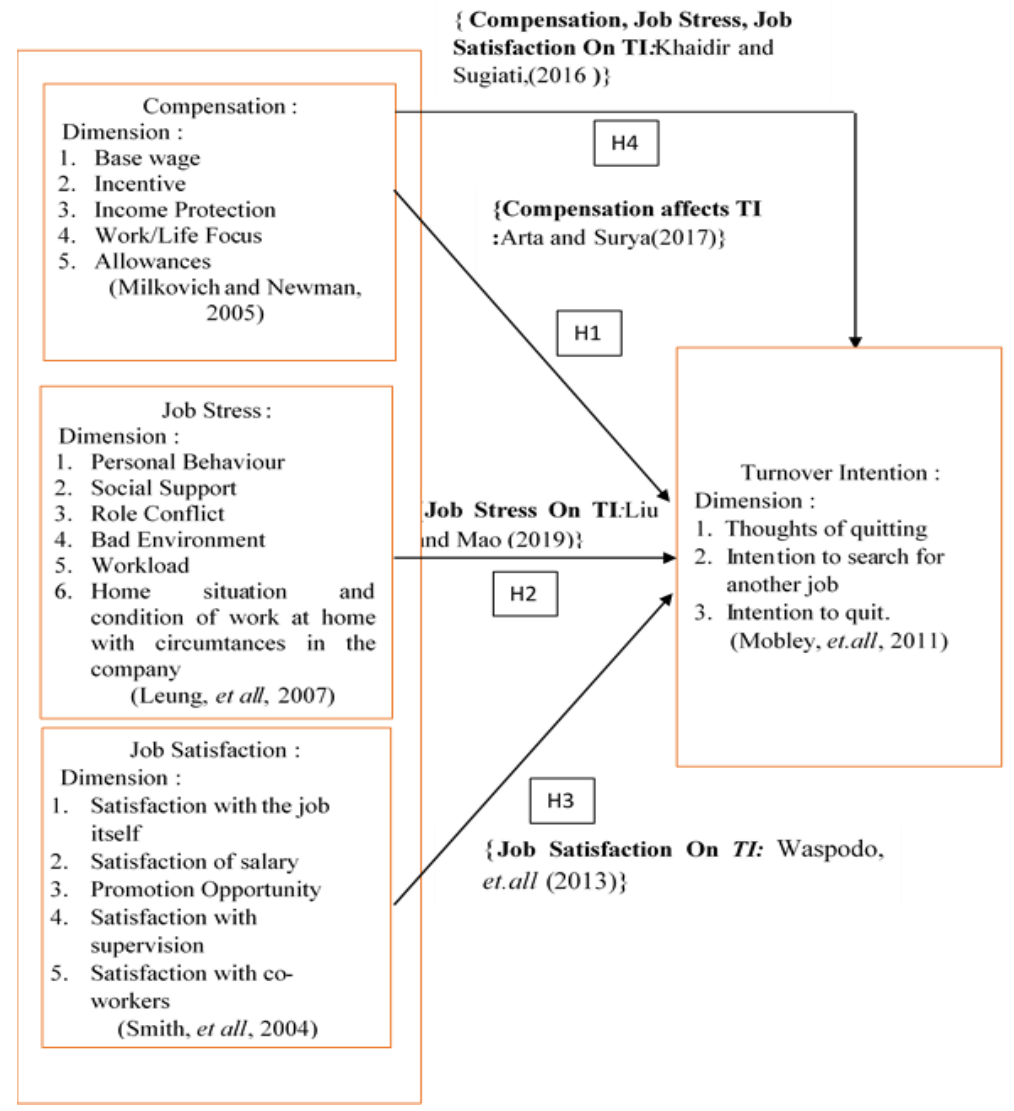

Picture 1 Theoretical Framework

\section{RESULT AND DISCUSSION}

Based on the calculation of the validity test it is known that the questions of all variables have a value of $r$ score $>0.361$ so that it can be concluded that all questions are declared valid and means that the indicator is good for measuring latent variables appropriately. Based on calculations it is known that all variables have a Cronbach value $>0.837-0.876$ so that it is stated that all questions in each variable are strongly reliable.

Table 1 Respondents Description

\begin{tabular}{llcc}
\hline & Characteristics & Qty & \% \\
\hline \multirow{2}{*}{ Sex } & Male & 8 & $8 \%$ \\
& Female & 92 & $92 \%$ \\
\hline \multirow{3}{*}{ Age } & $<21-30$ years old & 65 & $65 \%$ \\
& $31-40$ years old & 32 & $32 \%$ \\
& $41-50$ years old & 3 & $3 \%$ \\
\multirow{5}{*}{ Education } & $>50$ years old & 0 & $0 \%$ \\
& Middle school & 0 & $0 \%$ \\
& High School & 0 & $0 \%$ \\
& D3-Nursing & 97 & $97 \%$ \\
\multirow{3}{*}{ Years of Service } & $31-$ Nuring & 3 & $3 \%$ \\
& <1 year & 9 & $9 \%$ \\
& $1-3$ years & 45 & $45 \%$ \\
& $3-5$ years & 11 & $11 \%$ \\
\hline
\end{tabular}

Source: (Data analysis, 2020)

Based on Table 1 most of respondents are female (92\%), ages $21-30$ years $(65 \%)$, last education is college (100\%), and most respondents have worked for 1-3 years (45\%). 


\section{Descriptive Analysis (Three Box Method)}

The resulting index numbers show a score of 80 , by using the three-box method, so $80 / 3=26.6$. So, the range of the scale of each criterion is 26.6 , which will be used as a list of index interpretations as follows:

$$
\begin{aligned}
& 20-46.6 \quad: \text { Low } \\
& 46.6-73.3: \text { Medium } \\
& 73.3-100: \text { High }
\end{aligned}
$$

\section{a. Analysis on Turnover Intention}

The average value for the turnover intention variable is 67.03 and belongs to the medium category. This indicates that the turnover intention at Ananda Bekasi Hospital is in the medium category. The highest index is in the statement "I am no longer comfortable with this job, so it is better to find another job", and "Currently I am looking for a new job", with an index value of 70.6. This shows that most of the nurses at Ananda Bekasi Hospital are no longer comfortable working and are looking for work elsewhere. This should be a concern for Ananda Bekasi Hospital, as a high turnover rate will result in losses for the Hospital.

\section{b. Analysis on Compensation}

Compensation for no. 1 to no. 10 falls into the medium category, so this indicator is good for measuring other indicators precisely. The average value for the compensation variable is 57.48 and belongs to the medium category. This indicates that the provision of compensation at Ananda Bekasi Hospital is in the medium category. The highest index is in the statement "In this hospital, I get health insurance", with an index value of 68.5. This confirms that Ananda Bekasi Hospital takes care of its employees by facilitating them through health insurance. The lowest index is found in the statement "wages that I earn from this hospital were able to fulfill my daily life", which indicates that wages at Ananda Bekasi Hospital are still insufficient to meet the daily needs of their nurses.

\section{c. Analysis on Job stress}

The average value for the job stress variable is 65.94 and belongs to the medium category. This indicates that the job stress felt by nurses at Ananda Bekasi Hospital is classified as medium. The highest index is in statement "I have colleagues who support me" with an index value of 75.4. This shows that nurses at Ananda Bekasi Hospital have a good relationship with their colleagues. This is possible because some nurses at Ananda Hospital have colleagues who support each other.

\section{d. Description of Job Satisfaction}

The average value for the job satisfaction variable is 60.62 and included in the medium category. This indicates that the job satisfaction of nurses in Ananda Bekasi Hospital is classified as medium. The highest index is "I always work compactly with the team", with an index value of 68.8. This shows that nurses at Ananda Bekasi Hospital when collaborating with colleagues are always on the same page. The lowest index is found in the statement "my salary meets the Regional Minimum Wage (UMR) Standard", informing that most nurses at Ananda Bekasi Hospital have salary levels below the UMR standard.

Table 2 Three Box Recapitulation

\begin{tabular}{lccccc}
\hline \multirow{2}{*}{ Variables } & \multicolumn{3}{c}{ Indicator } & \multirow{2}{*}{ Avg. Index } & \multirow{2}{*}{ Category } \\
\cline { 2 - 4 } & Low & Medium & High & & medium \\
Compensation & 0 & 10 & 0 & 57.48 & medium \\
Jos Stress & 0 & 10 & 0 & 65.94 & medium \\
Job Satisfaction & 1 & 9 & 0 & 60.62 & medium \\
Turnover Intention & 0 & 6 & 0 & 67.03 & \\
\hline
\end{tabular}

Source: (Data analysis, 2020)

Multiple Linear Regression Test Results

Table 3 F Test Result

$\begin{array}{lllllll}\text { Model } 1 & \text { Sum of Squares } & \text { df } & \text { Mean Square } & \text { F } & \text { Sig. } & \text { Hyp. }\end{array}$




\begin{tabular}{lcccccc}
\hline Regression & 987.811 & 3 & 329.270 & 34.434 & $.000^{\mathrm{b}}$ & H4 Accepted \\
Residual & 917.979 & 96 & 9.562 & & & \\
Total & 1905.790 & 99 & & & & \\
\hline
\end{tabular}

a. Dependent Variable: Turnover Intention

b. Predictors: (Constant), Job Satisfaction, Job stress, Compensation

Source: (Data analysis, 2020)

Based on Table 3 presented above, it is known that the $\mathrm{F}$ value is 34.434 which is greater than $\mathrm{F}$ table $=2.699$ and with a significant probability of 0.000 which is much smaller than 0.05 , it can be said that the independent variables (compensation, job stress and job satisfaction) simultaneously have a significant effect on the dependent variable (turnover intention).

Table 4 Result of t Test

\begin{tabular}{lcccccc}
\hline \multirow{2}{*}{ Model 1 } & \multicolumn{2}{c}{ Unstandardized Coefficients } & $\begin{array}{c}\text { Standardized } \\
\text { Coefficients }\end{array}$ & \multirow{2}{*}{ T } & Sig. & Hyp \\
\cline { 2 - 4 } & $\mathbf{B}$ & Std. Error & Beta & & & \\
\hline (Constant) & 18.987 & 3.146 & & 6.036 & .000 & \\
Compensation & -.153 & .050 & -.255 & -3.081 & .003 & H1 accepted \\
Job stress & .304 & .063 & .383 & 4.793 & .000 & H2 accepted \\
Job Satisfaction & -.148 & .044 & -.281 & -3.401 & .001 & H3 accepted \\
\hline
\end{tabular}

a. Dependent Variable: Turnover Intention

Source: (Data analysis, 2020)

Based on Table 4 it can be seen that:

1. Compensation has a negative and significant effect on turnover intention because $\mathrm{t}$ score $=-3.081$ where this value is greater than $\mathrm{t}$ table $= \pm 1.985$ and the significance value is 0.003 or smaller than 0.05 .

From previous research ${ }^{10}$ it was found that compensation has a significant effect on turnover intention. Similarly, other research ${ }^{11-}$ 14 stated that the compensation variable has a negative and significant effect on turnover intention, and Kelly ${ }^{15}$ found that there is an effect of the independent variables of employee compensation on the dependent variable of employee turnover intention in the multi-faceted health care system in the US. This study confirms that the higher compensation received, the intention to leave the job will be reduced. It is because employees feel valued when their needs can be fulfilled.

2. Job stress has a positive and significant effect on turnover intention because $t$ score $=4.793$ where this value is greater than $\mathrm{t}$ table $= \pm 1.985$ and the significance value is 0,000 or smaller than 0.05 .
The results of this study support previous studies conducted by several previous researchers, including Liu et al. ${ }^{18}$. The results show that the turnover intention of health workers in western China is significantly related to stress, so it can be effective in reducing the intention to move to other companies by health workers. Similarly, other research $^{11,19-21}$ stated that job stress affects turnover intention. Nurses must deal with the lives of many people every day. The perceived burden includes physical and psychological. So, the higher the level of job stress experienced by an employee in working in the company will have an impact on the desire to leave the company.

3. Job satisfaction has negative and significant effect on turnover intention because $\mathrm{t}$ score $=-3.401$ where this value is greater than $\mathrm{t}$ table $= \pm 1.985$ and the significance value is 0.001 or smaller than 0.05 .

Results of this study are in line with the results of previous studies ${ }^{14,18,19,24-26}$ who all stated that turnover intention is influenced by employee job satisfaction. People with a high level of job satisfaction shows a positive attitude towards his work, but people who is 
dissatisfied with his job shows a negative attitude towards the job. Job satisfaction is related to the attitude of workers towards their work. If an employee feels dissatisfied with his job, the employee will likely leave his job.

\section{Effects of Compensation, Job stress and Job Satisfaction on Turnover Intention}

Mobley ${ }^{17}$ stated that turnover intention is the result of an individual evaluation of the continuation of the relationship with the company where he works but has not been manifested in concrete actions. The results of this study are in line with the results of the previous studies ${ }^{11,15,18,20,24}$ who are all stated that compensation, job stress, and job satisfaction have an effect on turnover intention. When employees feel the compensation, they earn is not enough to meet their daily needs, job stress they experienced increases and job satisfaction cannot be obtained, causing an intention of turnover intention because essentially, people will look for better opportunities.

\section{Theoretical Implications}

The results of this study successfully proved that three factors can affect the level of turnover intention, which are compensation, job stress, and job satisfaction. These three factors have been proven to significantly affect turnover intention. And this research can be used as insight for further researchers.

\section{Managerial Implications}

Job stress means difficulties, workload, and discomfort felt by nurses. The results of this study indicate that the job stress variable affects turnover intention. This implies that the Ananda Bekasi Hospital is expected to be able to maintain working conditions that can trigger job stress for its workers in this case is to maintain a good relationship among fellow nurses, because this is the highest indicator in this study. Good support from co-workers can reduce high levels of job stress in a work environment. And hopefully, the hospital is able to provide job stress training for nurses with the goal of employees having endurance over stress and having a better ability to cope with job stress. To obtain maximum results, the training must be handled by people who are experts in the stress-handling field.

\section{CONCLUSION}

There is a negative and significant effect of compensation on turnover intention, which implies that the lower the compensation received will increase turnover intention. A positive and significant effect of job stress on turnover intention confirms that the higher job stress experienced will increase turnover intention. A negative and significant effect of job satisfaction on turnover intention means that lower job satisfaction will increase turnover intention. There are effects of compensation, job stress, and job satisfaction on turnover intention, confirming that compensation, job stress, and job satisfaction could affect the level of turnover intention.

\section{ACKNOWLEDGMENT}

The Author would like to express her highest gratitude to Dr. Rokiah Kusumapradja, MHA as the head of Hospital Administration Management Program at Esa Unggul University, Dr. Rina Anindita, SE, MM, and M. Reza Hilmy, SKM, MARS, PhD as supervisors in this research process. Also, to Dr. dr. Titi Masrifahati, MKM, MARS as the Director of Ananda Bekasi Hospital for the support and the permission given to conduct the research at the hospital, and the Inpatient Nurses involved in this research.

\section{REFERENCES}

1. Hidayati N, Trisnawati D. Pengaruh kepuasan kerja dan stress kerja terhadap turnover intentions karyawan bag. marketing PT. Wahana Sahabat Utama. EKSIS. 2016;11(1):22-37.

2. Hart SE. Hospital ethical climates and registered nurses' turnover intentions. J Nurs Scholarsh. 2005 Jun;37(2):173-7.

3. Fitzpatrick JJ. Joint Commission on Accreditation of Health Care Organizations White Paper: Health care at the crossroads: Strategies for addressing the evolving nursing crisis. Policy, Polit Nurs Pract. 2003 Feb;4(1):71-4. 
4. Draper NR, Smith H. Applied Regression Analysis, 3rd Edition. 3rd ed. New York: Wiley-Interscience; 1998. $736 \mathrm{p}$.

5. Dessler G. Human resources management. 14th ed. Upper Saddle River: Pearson Education; 2016.

6. Leung M, Sham J. Adjusting Stressors - Job-Demand Stress in Preventing Rustout / Burnout in Estimators. Surv Built Environ. 2007;18(June):17-26.

7. Arta IGNW, Surya IBK. Pengaruh kompensasi terhadap komitmen organisasional dan turnover intention pada Agent Pru Megas. E-Jurnal Manaj Unud. 2017;6(8):4156-84.

8. Khaidir M, Sugiati T. Pengaruh stres kerja, kompensasi dan kepuasan kerja terhadap turnover intention studi pada karyawan kontrak PT. Gagah Satria Manunggal Banjarmasin. J Wawasan Manaj. 2016;4(3):175-85.

9. Rohmanaji D, Warso MM, Paramita PD. Pengaruh reward, salary dan job satisfaction terhadap turnover intention karyawan di Sarinah Shop and Tailor. J Manage. 2016;2(2):1-21.

10. Tantowi A, Said LR, Rahmawati R. Pengaruh kompensasi finansial dan non finansial terhadap kepuasan kerja serta dampaknya terhadap turnover intention pada pelaut Di PT. Maritim Barito Perkasa Banjarmasin. J Wawasan Manaj. 2016;4(1):11-22.

11. Zaki H, Marzolina. Pengaruh beban kerja dan kompensasi terhadap turnover intention melalui kepuasan kerja pada karyawan PT. Adira Quantum Multifinance cabang Pekanbaru. J Tepak Manaj Bisnis. 2016;8(3):1-23.

12. Kelly DR. Antecedents influencing retention of healthcare employees within the United States: A quantitative correlational study. University of Phoenix; 2019.

13. Liu J, Zhu B, Wu J, Mao Y. Job satisfaction, job stress, and turnover intentions among rural health workers:
A cross-sectional study in 11 Western Provinces of China. BMC Fam Pract. 2019;20(1):1-11.

14. Applebaum DH. The relationship between physical work environmental factors, perceived stress, job satisfaction and turnover intention among inpatient acute care nurses. Rutgers, The State University of New Jersey; 2008.

15. Irvianti LSD, Verina RE. Analisis pengaruh stres kerja, beban kerja dan lingkungan kerja terhadap turnover intention karyawan pada PT XL Axiata Tbk Jakarta. Binus Bus Rev. 2015;6(1):117-26.

16. Z IN, Prasetio AP. Pengaruh tres kerja terhadap turnover intention pada karyawan CV. Sukahati Pratama. Study Manag Res. 2017;14(3):57-64.

17. Waspodo AA, Handayani NC, Paramita W. Pengaruh kepuasan kerja dan stres kerja terhadap turnover intention pada karyawan PT. Unitex di Bogor. J Ris Manaj Sains Indones. 2013;4(1):97115.

18. Zhang W, Meng H, Yang S, Liu D. The influence of professional identity, job satisfaction, and work engagement on turnover intention among township health inspectors in China. Int $\mathbf{J}$ Environ Res Public Health. 2018;15(5):1-13.

19. Edwards-Dandridge YM. Work engagement, job satisfaction, and nurse turnover intention. Walden University; 2019.

20. Mobley WH. Pergantian karyawan: Sebab, akibat dan pengendaliannya. Imam N, editor. Jakarta: PT Pustaka Binaman Pressindo; 2011. 